\title{
PENGARUH BAHAN PENGENTAL PADA SAUS TOMAT
}

\author{
THICKENER MATERIAL EFFECT IN TOMATO SAUCE
}

\author{
Sjamsiwarni Reny Sjarif dan Shinta Wahyu Apriani \\ Balai Riset dan Standardisasi Industri Manado \\ Jalan Diponegoro No: 21-22 Manado \\ Pos-el: Reny sjarif@yahoo.co.id \\ Diterima tgl 10-08-2016, Disetujui tgl 22-09-2016
}

\begin{abstract}
ABSTRAK
Buah tomat merupakan komoditi hortikultura yang mudah mengalami kerusakan karena kandungan air yang tinggi. Salah satu cara pengolahannya adalah membuat menjadi produk saus tomat dengan penambahan bahan pengental. Tujuan penelitian ini untuk membuat produk saus tomat dan mengetahui pengaruh bahan pengental terhadap mutu fisikokimia saus tomat. Penelitian dilakukan dengan perlakuan bahan pengental yaitu hunkuwe/pati kacang hijau, maizena/pati jagung, tapioka dan karagenan sebanyak 7\% dengan tambahan bahan lain sejumlah konstan. Penelitian ini dilakukan dengan metode deskriptif ditampilkan dalam bentuk tabel dan gambar. Parameter yang diuji berdasarkan SNI mutu saus tomat.Dari hasil penelitian menunjukkan bahwa produk saus tomat yang dihasilkan dengan menggunakan pengental hunkuwe, maizena, tapioka dan karagenan tidak berpengaruh terhadap fisik produk saus tomat seperti bau,rasa dan warna yaitu normal khas tomat. Jumlah padatan terlarut untuk bahan pengental hunkuwe 42,3; maizena 42,2; tapioka 41,3 dan karagenan $41,5 \mathrm{Brix}, 20^{\circ} \mathrm{C}$. Hasil uji keasaman dihitung sebagai asam asetat untuk hunkuwe 2,25; maizena 2,46; tapioka 2,55 dan karagenan $2,51 \%$. Angka lempeng total berkisar antara $2,2 \times 10^{1}-9,3 \times 10^{1}$ koloni/g dan kapang berkisar antara $1 \times 10^{1}-$ $5 \times 10^{1} \mathrm{koloni} / \mathrm{g}$. Uji organoleptik terhadap tekstur produk saus tomat diperoleh skor tertinggi 3,7 yaitu agak suka sampai suka dengan bahan pengental karagenan. Dibandingkan dengan SNI 01-3546-2004 tentang syarat mutu saus tomat memenuhi syarat mutu untuk semua kriteria parameter yang diujikan dalam penelitian ini.
\end{abstract}

Kata kunci: Saus tomat,hunkuwe, maizena, tapioka, karagenan

\section{ABSTRACT}

Tomato fruit is a perishable horticulture commodity due to high water content. One way to process by processing into tomato sauce products with the addition of thickening agents. The purpose of this study is to make tomato sauce to determine the effect of thickening on the physicochemical quality. Research carried out by the thickening treatment of hunkuwe/mung bean starch, maize/corn starch, tapioca and carrageenan in as much as $7 \%$ with the addition of another ingredients in constant amount. The study was conducted by descriptive method shown in the form of tables and pictures. The parameters tested based on SNlabout tomato sauce quality. The results showed that tomato sauce product produced using hunkuwe thickener, cornstarch, tapioca and carrageenan had no dwindling effect on the product's physical tomato sauce of smell, taste and color that is typical of normal tomatoes. Total dissolved solids for thickening hunkuwe 42.3,cornstarch 42.2, tapioca 41.5 and carrageenan 41.3 Brix, $20{ }^{\circ} \mathrm{C}$. The acidity calculated as acetic acid of hunkuwe 2.25, 2.46 cornstarch, tapioca 2.55 and 2.51\% carrageenan.Microbial contamination of total plate count ranged from $2,2 \times 10^{1}-9,3 \times 10^{1}$ colonies $/ g$ and molds ranged $1 \times 10^{1}-\times 10^{1}$ colonies/g. Organoleptic assessment of tomato sauce texture obtained the highest score of 3.7 which is a bit like until like for carrageenan. Compared with the quality requirements of SNI 01-3546-2004, all tomato sauces meet the quality requirements for all criteria of the parameters tested in this study.

Keywords: tomato sauce, hunkuwe, cornstarch, tapioca starch, carrageenan

\section{PENDAHULUAN}

Buah tomat merupakan komoditi hortikultura, buah tomat mudah mengalami kerusakan jika tidak disimpan pada kondisi yang baik. Besarnya kerusakan buah tomat setelah panen berkisar antara $20 \%$ sampai dengan $50 \%$ (1).Salah satu cara untuk memperpanjang masa simpan buah tomat dengan mengolahnya menjadi produk olahan.Tomat sebagai sumber pangan dan mineral mengandung vitamin yang tinggi terdiri atas vitamin $C$, Vitamin B, Vitamin $E$ dan provitamin A karoten, sedangkan mineral yang dikandung $\mathrm{Ca}, \mathrm{Mg}, \mathrm{P}, \mathrm{K}, \mathrm{Na}$, 
Fe, sulfur dan klorin (2).Dalam 100 gram tomat dapat menyumbangkan sekitar 10$20 \%$ vitamin A (3).Selain vitamin dan mineral, tomat juga mengandung pigmen pemberi warna merah yang terdeteksi didominasi oleh likopen. Tomat segar mengandung likopen antara 3 dan 5 ppm, sedangkan konsentrat likopen dari pasta tomat mengandung 50\% likopen (4).

Saos tomat adalah salah satu bentuk olahan yang dipergunakan sebagai bahan penyedap makanan, Saus tomat biasanya menjadi pelengkap hidangan seperti bakso, mie ayam, gorengan, dan masih banyak lagi.Saos tomat merupakan produk yang dihasilkan dari campuran bubur tomat atau pasta tomat, diperoleh dari tomat yang masak, diolah dengan bumbu-bumbu dan bahan tambahan pangan (5). Mutu saus tomat ditentukan berdasarkan berbagai parameter yaitu derajat keasaman $(\mathrm{pH})$ berkisar3-4, total padatan terlarut $30^{\circ}$ brix, serta penilaian terhadap warna, bau dan rasa khas tomat, oleh karena itu perlu dilakukan penambahan bahan pengisi untuk meningkatkan kekentalan saus tomat (6).

Kekentalan merupakan sifat fisik yang terpenting dalam produk saos tomat yang menentukan tekstur saos dan mempengaruhi konsistensi dari saos itu sendiri selama penyimpanan. Tidak terjadi penggumpalan dan mempunyai warna cerah. Tingkat kekentalan tersebut dapat dibantu dengan penambahan bahan pengental berupa pati. Pati dapat berperan sebagai pengental saos tomat dengan memanfaatkan prinsip gelatinisasi pati. Saat larutan pati dipanaskan akan terjadi gelatinisasi pati, yang dicapai setelah beberapa waktu pemanasan.Pati yang umum digunakan dalam pembuatan saos tomat komersial adalah maizena,tapioka, ataupun pati termodifikasi. Pati termodifikasi dipergunakan untuk memproduksi saos tomat skala besar oleh pabrik. Terdapat alternatif bahan pengental saos tomat kental yaitu CMC, pectin dan karagenan (7). Sedangkan bahan pengental buatan seperti $\mathrm{CMC}$ (carboxymethil cellulose) tidak mengandung unsur- unsur yang bermanfaat bagi kesehatan (8). Bahanbahan ini berpotensi sebagai bahan pengental dalam pembuatan saos tomat. Bahan pengental yang digunakan pada penelitian ini yaitu karagenan, tapioka, maizena dan hunkuwe.

Karagenan diperoleh melalui ekstraksi dari rumput laut yang dilarutkan dalam air atau larutan basa kemudian diendapkan menggunakan alkohol atau $\mathrm{KCl}$.Karagenan adalah senyawa yang diekstraksi dari rumput laut dari Famili Rhodophyceae seperti Euchema spinosum dan Euchema cottonii yang terdiri dari rantai poliglikanbersulfat dengan massa molekuler (Mr) kurang lebih di atas 100.000 serta bersifat hidrokoloid. Karagenan digunakan pada makanan sebagai bahan pengental, pembuatan gel, dan emulsifikasi (9).

Tapioka merupakan salah satu bentuk olahan berbahan baku singkong, Tepungtapioka mempunyai banyak kegunaan, antara lain sebagai bahan pembantu dalamberbagai industri. Komposisi zat gizi tepung tapioka lebih baik bila dibandingkandengan tepung jagung, kentang, gandum atau terigu. Tepung tapioka juga dapatdigunakan sebagai 
bahan bantu pewarna putih (10).Pati jagung atau maizena merupakan salah satu produk dari hasil pengolahan jagung pasca panen. Maizena merupakan homopolimer glukosa dengan ikatan $\alpha$-glikosidik, yang terdiri dari dua fraksi yang dapat dipisahkan dengan air panas yaitu fraksi terlarut amilosa dan fraksi tidak terlarut disebut amilopektin (11).

Bahan dasar pembuatan hunkuwe yaitu kacang hijau. Kacang hijau adalah tanaman pangan legum mengandung gizi yang bermanfaat bagi tubuh manusia. Pada 100 gr kacang hijau mengandung pati $67,22 \mathrm{gr}$, protein $27,10 \mathrm{gr}$, dan lemak 1,78 gr (12).Hunkuwe mampu membentuk gel sehingga dapatdigunakan sebagai bahan pengental.

Penelitian ini dilakukan untuk mendapatkan produk saos tomat dengan bahan pengental yang dapat memenuhi syarat mutu produk saos tomat.

\section{BAHAN DAN METODE}

\section{Bahan dan Alat}

Bahan yang digunakan dalam penelitian ini adalah: buah tomat matang segar diperoleh dari pasar lokal Manado, natrium benzoate, bumbu tambahan (bawang putih, gula, garam, penyedap, cuka) dan bahan pengental sebagai perlakuan (pati kacang hijau/hunkuwe,pati jagung maizena, tapioka dan karagenan)

Alat-alat yang digunakan dalam penelitian ini terdiri dari: blender, panci, loyang, sendok, pisau, baskom,kompor,saringan dan botol untuk kemasan.

\section{Metode Penelitian}

Penelitian ini menggunakan metode percobaan deskriptif dengan dua kali ulangan. Perlakuan yang digunakan yaitu $7 \%$ untuk bahan pengental (Karagenan, maizena, hunkuwe dan tapioka). Bumbu yang digunakan antara lain garam $5 \%$, gula pasir $22 \%$, bawang putih $1,5 \%$, larutan cuka $25 \% 47 \mathrm{ml}$, sodium benzoate $0,7 \%$, pewarna(ponceau ${ }_{4} \mathrm{R} \mathrm{Cl}$ 16255) $0,7 \%$.).

\section{Prosedur Penelitian}

Proses pembuatan saus tomat (12) adalah sebagai berikut:

\section{Tahap Pembuatan Bubur}

Pertama tomat yang akan digunakan dan diolah dipilih buah segar dengan tingkat kematangan yang merata dan tidak cacat. Kedua, buah tomat yang telah dipilih dicuci dengan air bersih agar terbebas dari segala kotoran yang masih melekat pada buah tomat. Ketiga, pemanasan pendahuluan (blanching) buah tomat yang sudah bersih diblansir selama 3 menit. Tujuan dari pemanasan pendahuluan yaitu untuk mengurangi jumlah mikroba pada tomat dan sekaligus menonaktifkan enzim penyebab perubahan warna. Buah tomat yang telah diblansirdikupas kemudian dihancurkan sampai halus dan berbentuk bubur yang lembut dengan menggunakan mesin penggiling atau blender.Setelah proses penggilingan selanjutnya dilakukan proses penyaringan untuk memisahkan bijinya 
sehingga diperoleh bubur tomat yang bersih.

\section{Pemasakan Saus Tomat}

a. Pendidihan:Bubur buah tomat direbus sampai mendidih dan dimasak sampai mengental dengan api kecil pada suhu $80^{\circ} \mathrm{C}$

b. Pemberian bumbu: Pada saat pendidihan bubur tomat ditambahkan bumbu-bumbu yang telah dihaluskan (garam 5\%, gula pasir $22 \%$, bawang putih $1,5 \%$, larutan cuka $25 \% \quad 47 \mathrm{ml}$,sodium benzoate $0,7 \%$, pewarna(ponceau $\left.{ }_{4} \mathrm{R} \mathrm{Cl}_{16255}\right)$ 0,7\%.)

c. Penambahan bahan pengental Bahan pengental sesuai perlakuan (hunkuwe/pati kacang hijau,maizena,tapioka atau karagenan) sebanyak 7\% yang terlebih dahulu dilarutkan dengan air $100 \mathrm{ml}$.

Proses pemasakan saus tomat dapat dilihat pada Gambar 1.

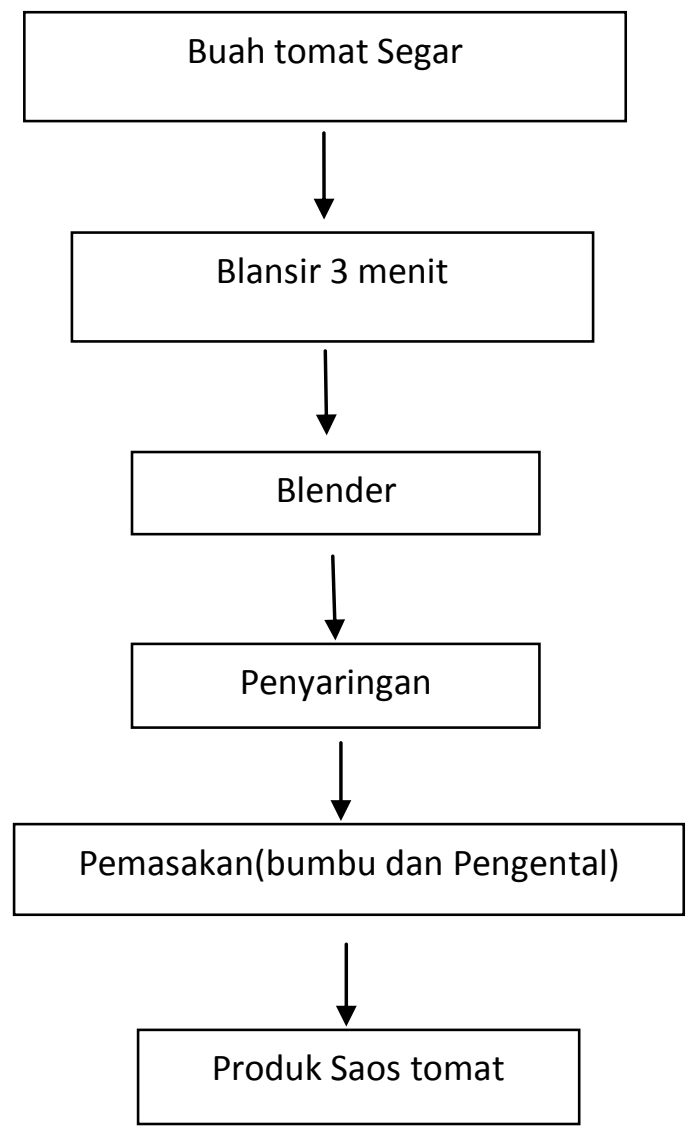

Gambar 1. Diagram alir pembuatan saus tomat

\section{Pengamatan}

Pengamatan dilakukan terhadap mutu produk saos tomat dengan SNI 013546-2004 (13), antara lain jumlah padatan terlarut dengan menggunakan alat refraktometer, keasaman dihitung sebagai asam asetatdengan metode titrimetri, cemaran mikrobaangka lempeng total dan jumlah kapang dengan metode tuang. Dilakukan juga uji organoleptik(bau, rasa, warna dan tekstur) dengan skala hedonik. 


\section{HASIL DAN PEMBAHASAN}

\section{Bahan Baku Tomat}

Buah tomat yang digunakan berasal dari pasarKota Manado. Buah tomat yang sudah matang warnanya oranye kemerahmerahan. Dari $1 \mathrm{~kg}$ buah tomat segar didapatkan $700 \mathrm{~g}$ bubur tomat setelah diblender dan disaring,sisanya yaitu sebanyak $300 \mathrm{~g}$ tidak digunakan yaitu kulit dan biji buah tomat.

Hasil Pengamatan Fisiko Kimia Produk Saos Tomat dengan Bahan Pengental yang digunakan

Hasil pengamatan fisiko kimia produk saus tomat dilakukan secara organoleptik. Hasilnya dapat dilihat pada Tabel.3

Tabel 3. Hasil Pengamatan Keadaan Fisik Bau, Rasa dan Warna

\begin{tabular}{lccc}
\hline $\begin{array}{c}\text { Bahan } \\
\text { Pengental }\end{array}$ & Bau & Rasa & Warna \\
\hline Hunkuwe & Normal & Normal khas tomat & Normal \\
Maizena & Normal & Normal khas tomat & Normal \\
Tapioka & Normal & Normal khas tomat & Normal \\
Karagenan & Normal & Normal khas tomat & Normal \\
\hline
\end{tabular}

Data pada Tabel 3. produk saos tomat dengan menggunakan bahan pengental hunkuwe, maizena, tapioka dan karagenan menunjukkan bau normal(bau khas saos tomat), rasanya normal khas tomat dan warnanya normal memenuhi persyaratan SNI 01-3546-2004(13)tentang keadaan saos tomat.

\section{Jumlah Padatan Terlarut Saus Tomat}

Cara uji jumlah padatan terlarut menggunakan alat refraktometer (14). Dan hasil pengujian jumlah padatan terlarut dapat dilihat pada Gambar 2.

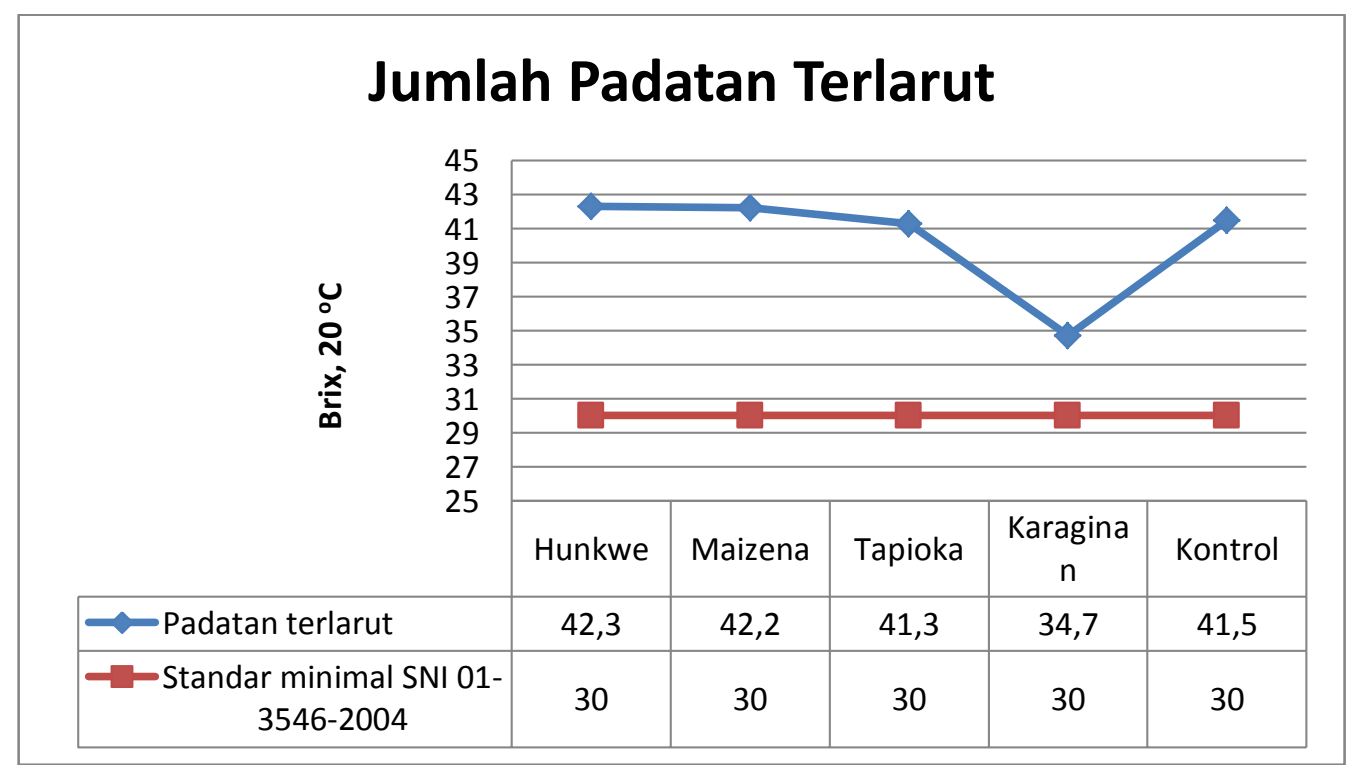

Gambar 2. Hasil Uji Jumlah Padatan Terlarut Saus Tomat 
Hasil pengujian jumlah padatan terlarut saus tomat dengan bahan pengental hunkuwe, maizena, tapioka dan karagenan berkisaran antara 34,7-42,3 Brix, $20^{\circ} \mathrm{C}$. Jumlah padatan terlarut tertinggi dengan penggunaan pengental hunkuwe 42,3 Brix, $20^{\circ} \mathrm{C}$ dan jumlah padatan terendah diperoleh dengan penggunaan bahan pengental karagenan $34,7 \mathrm{Brix}, 20^{\circ} \mathrm{C}$. Saus tomat biasanya mengandung tidak kurang dari $12 \%$ total solid tomat, karena saos tomat adalah bentuk dispersi zat-zat terlarut yang terkonsentrasi dalam media cair.

Penambahan karagenan sebagai penstabil emulsi akan menyebabkan peningkatan pada kekentalan dan stabilitas suspensi dalam hal ini karagenan akan membentuk suatu jaringan tiga dimensi yang dapat menghasilkan emulsi dan mencegah pengendapan sehingga air akan terperangkap dalam produk (15). Hasil yang diperoleh dari semua perlakuan pengental memenuhi persyaratan mutu saos tomat SNI 01-3546-2004 (13).

\section{Keasaman dihitung sebagai asam asetat}

Acuan cara uji keasaman (14) dengan prinsip banyaknya basa yang digunakan untuk titrasi menunjukkan jumlah asam yang terdapat dalam contoh. Hasil uji keasaman dihitung sebagai asam asetat dapat dilihat pada Gambar 3.

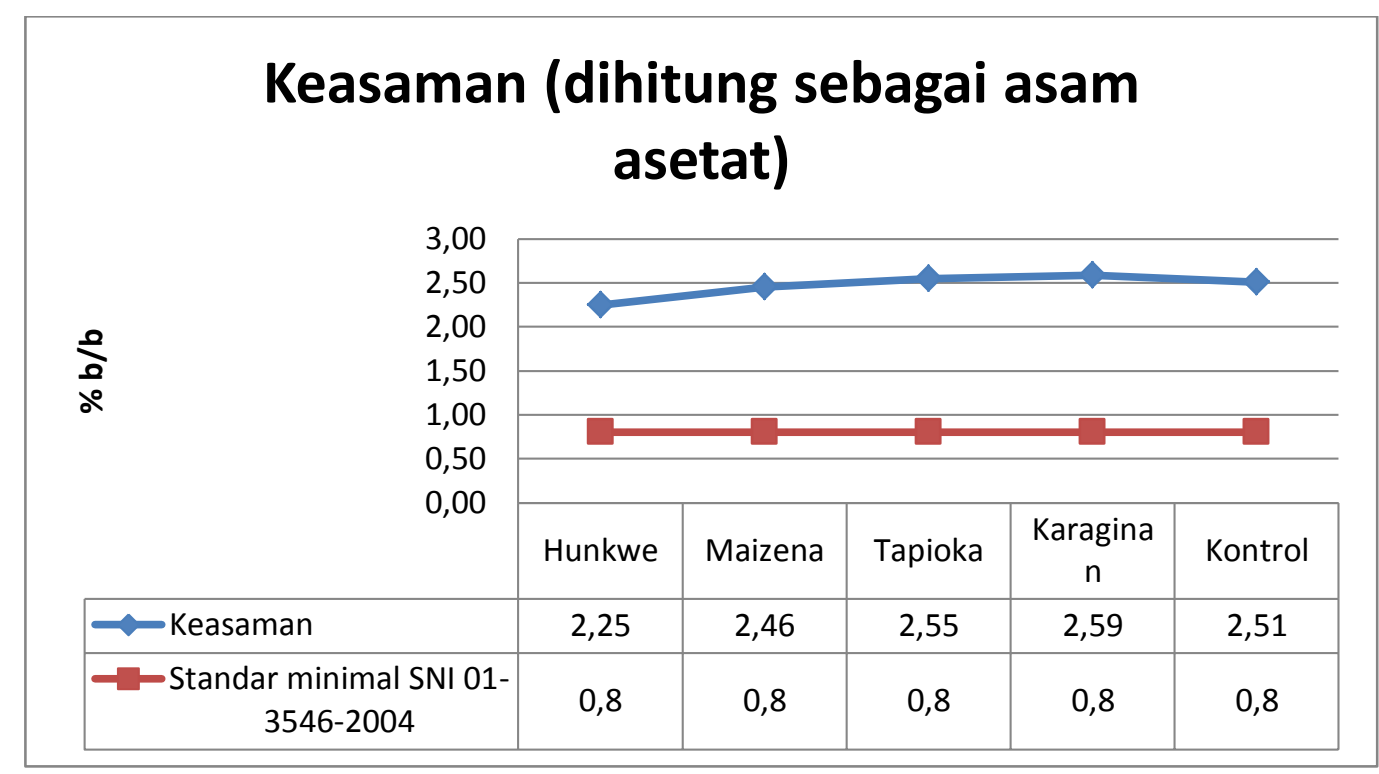

Gambar 3 Hasil Uji Keasaman, Dihitung sebagai Asam Asetat Produk Saus Tomat

Dari hasil uji keasaman, dihitung sebagai asam asetat pada produk saos tomat dengan perlakuan bahan pengental hunkuwe, maizena, tapioka dan karagenan diperoleh hasil berkisar antara 2,25- 2,59\%.
Dari hasil yang diperoleh sudah memenuhi syarat mutu SNI saus tomat hal ini diduga semua perlakuan bahan pengental dapat digunakan sebagai pembentuk gel dan tidak mudah terhidrolisis pada $\mathrm{pH}$ rendah. 


\section{Cemaran Mikroba}
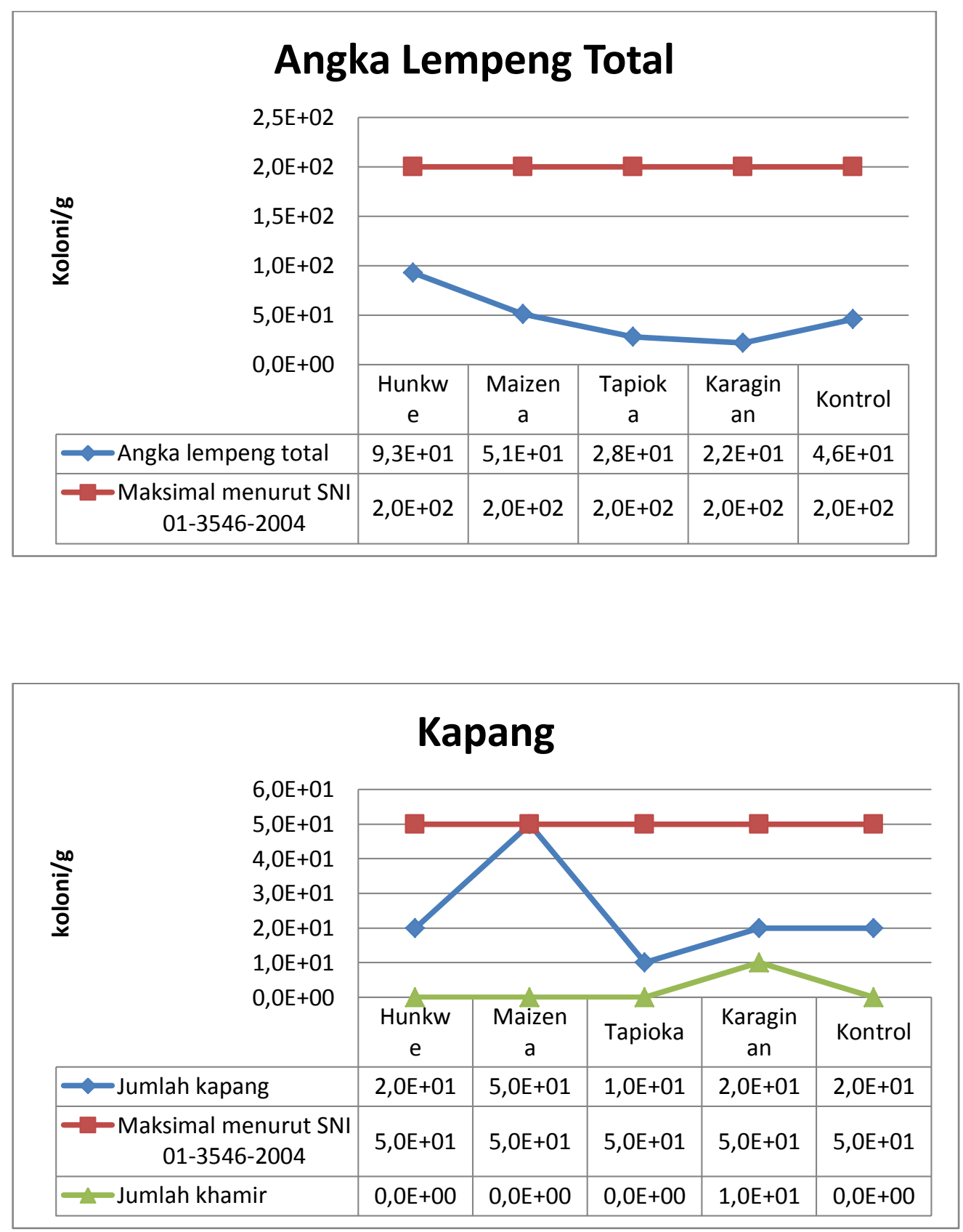

Gambar 4. Hasil Uji Cemaran Mikroba Produk Saus Tomat

Pada gambar 4 menunjukkan hasil uji cemaran mikroba baik angka lempeng total dan kapang dengan penggunaan bahan pengental hunkuwe,maizena, tapioka dan karagenan yaitu untuk angka lempeng total berkisar antara $2,2 \times 10^{1}-9,3 \times 10^{1}$ koloni/g sedangkan untuk kapang berkisar antara $1 \times 10^{1}-5 \times 10^{1} \mathrm{koloni} / \mathrm{g}$. Hal ini dikarenakan produk saus tomat tidak melewati proses penyimpanan, proses pembuatan dengan bahan berkualitas dan peralatan yang higenis juga menggunakan bumbu-bumbu seperti garam $\mathrm{NaCl}$, cuka, gula dan bawang putih yang berfungsi sebagai pemberi cita rasa. $\mathrm{NaCl}$ merupakan racun untuk jasad renik, mikroba perusak (16) dan jika bumbu 
dikombinasikan dengan asam, daya bunuh terhadap renik lebih kuat sebagai pengendali mikroorganisme (17).

\section{Uji Organoleptik}

Metode pengujian mutu organoleptik bahan pangan digunakan untuk membedakan kualitas bahan pangan pada aroma, rasa dan tekstur secara langsung. Mutu organoleptik dari suatu bahan pangan akan mempengaruhi diterima atau ditolak bahan pangan tersebut oleh konsumen sebelum menilai kandungan gizi dari bahan pangan (18). Hasil uji organoleptik terhadap tingkat kesukaan saus tomatdengan menggunakan skala hedonik dapat dilihat pada Gambar 5.

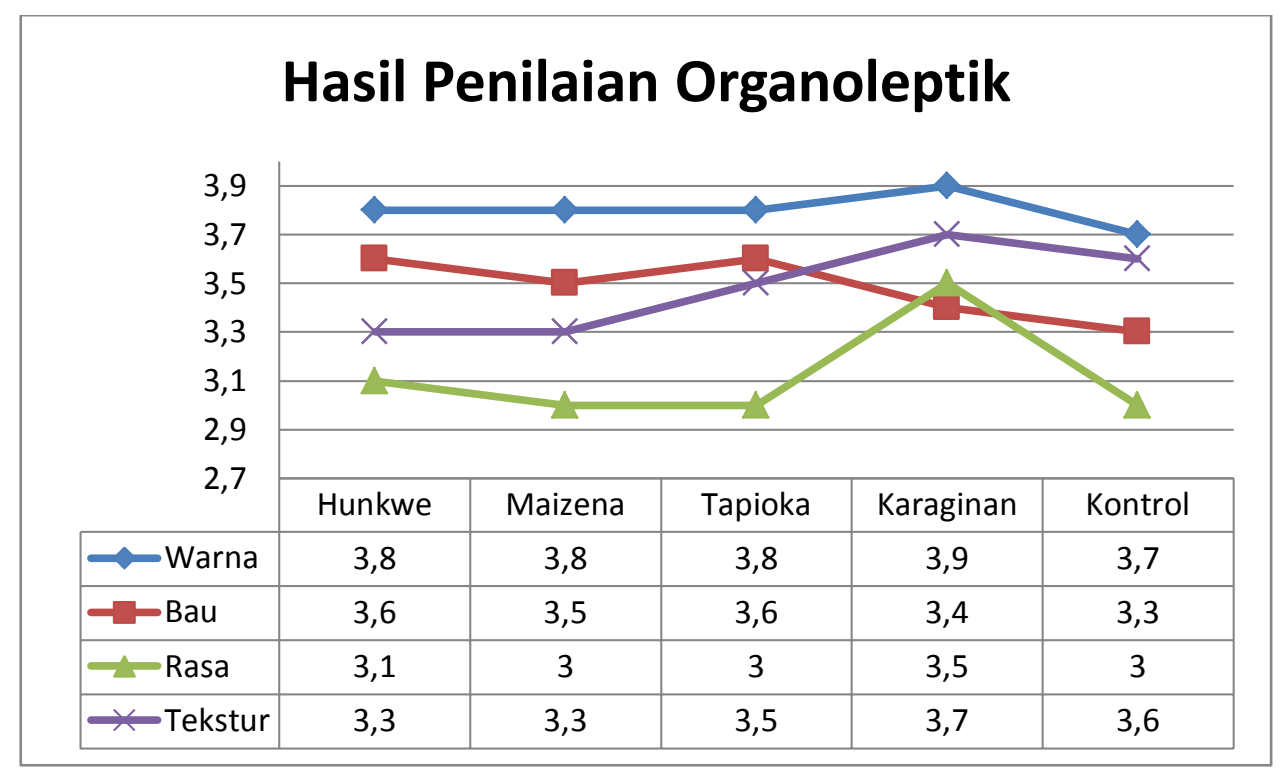

Gambar 5. Hasil Penilaian Organoleptik dengan Perlakuan Bahan Pengental

Hasil penilaian organoleptik terhadap warna dari saos tomat diperoleh nilai rata-rata tingkat kesukaan panelis berkisar antara 3,7-3,9 yaitu agak suka sampai suka. Produk saos tomat ditambahkan bahan $\begin{array}{llll}\text { pewarna makanan(ponceau } & 4_{R} & \mathrm{C}_{\mid 16255} \text { ) }\end{array}$ sesuai dengan takaran penggunaan $\mathrm{SNI}$ 01-02222-1995 (19) dan sesuai dengan peraturan dibidang makanan yang berlaku yaitu $1 \%$. Pewarna yang digunakan pada semua perlakuan sama yaitu sebanyak 0,7\% menghasilkan warna produk saos tomat oranye kemerah-merahan. Intensitas warna merah pada saus sangat dipengaruhi pada banyaknya zat warna yang ditambahkan.

Hasil penilaian terhadap bau saus tomat diperoleh rata-rata tingkat kesukaan panelis berkisar antara 3,3-3,6 yaitu agak suka sampai suka. Bau yang dihasilkan dari produk saus tomat dengan menggunakan pengental hunkuwe, maizena, tapioka dan karagenan memberikan bau khas saus tomat dimana pengental yang digunakan tidak mempunyai bau ciri khas yang khusus. Nilai tingkat kesukaan tertinggi diperoleh dari perlakuan bahan pengental hunkuwe dan tapioka yaitu 3,6, diduga bau 
yang disukai panelis dihasilkan dari penambahan bumbu.

Hasil penilaian terhadap rasa dari saus tomat diperoleh rata-rata tingkat kesukaan panelis berkisar antara 3-3,5 yaitu agak suka sampai dengan suka. Rasa yang dihasilkan dari produk saos tomat dengan nilai kesukaan tertinggi diperoleh dengan perlakuan karagenan yaitu 3,5. Bahan dasar dalam formulasi saus yaitu tomat,cuka,gula, garam, dan juga bahan pengental (20). Penilaian rasa dari panelis ada yang menyatakan asin dan ada juga yang menyatakan asam hal ini dikarenakan bahan atau bumbu-bumbu yang ditambahkan pada produk saus tomat.Penggunaan saus tomat ini sebagai bahan tambahan atau pelengkap di berbagai macam makanan.

Hasil penilaian terhadap tekstur saus tomat diperoleh rata-rata tingkat kesukaan panelis berkisar antara 3,3-3,7 yaitu agak suka sampai dengan suka. Tekstur yang dihasilkan dengan nilai kesukaan tertinggi dari produk saos tomat dengan menggunakan bahan pengental karagenan yaitu 3,7. Karagenan mempunyai fungsi sebagai stabilizer (penstabil),thickener (bahan pengental), pembentuk gel, pengemulsi (21).Saus tomat kental yaitu saus tomat yang memiliki viskositas tinggi, mempunyai sifat aliran diskontiyu, namun masih bisa mengalir keluar dari botol pengemas saos tomat.Pembentukan gel merupakan hasil crosslinking antara rantai heliks yang berdekatan, dengan grup sulfat(bersifat hidrofilik), banyaknya fraksi sulfat dan keseimbangan kation dalam air menentukan kekentalan atau kekuatan gel yang dibentuk karagenan (22).

\section{KESIMPULAN}

Dari perlakuan bahan pengental yang digunakan baik hunkuwe, maizena, tapioka dan karagenan diperoleh hasil yang memenuhi syarat mutu saus tomat SNI 013546-2004. Uji fisik produk saus tomat bau normal, rasa khas tomat dan warna normal. Jumlah padatan terlarut berkisar antara 34,7-42,3 Brix pada suhu $20^{\circ} \mathrm{C}$, keasaman dihitung sebagai asam asetat 2,25-2,59\%. Cemaran mikroba angka lempeng total berkisar antara $2,2 \times 10^{1}-9,3 \times 10^{1}$ koloni/g dan kapang berkisar antara1 $\times 10^{1}-5 \times 10^{1}$ koloni/g. Uji penilain organoleptik terhadap tekstur produk saus tomat diperoleh nilai 3,7 dengan bahan pengental karagenan.

\section{DAFTAR PUSTAKA}

1. WinarnoFG. Kimia pangan dan gizi. Jakarta: Gramedia Pustaka Utama; 1984.

2. Rahmat R. Tomat dan chery. Yogyakarta:Kanisius; 1994.

3. Astawan. Tepung tapioka, manfaatnya dan cara pembuatannya. Jakarta:Penebar Swadaya; 2009.

4. Wenli Y, Yaping Z, Zhen X, Hui J, Dapu $W$. The antioxidant properties of lycopene concentrate extracted from tomato paste. Journal of the American Oil Chemists' Society. 2001 Jul 1;78(7):697-701.

5. Wandestri, Hamzah F dan Harun N. Penambahan beberapa konsentrasi xanthan gum terhadap mutu saos tomat (Solanum lycopersicum Lin.,). Jom Faperta Vol. 3 No. 1, Fakultas Pertanian, Universitas Riau; 2016.

6. KoswaraS.2009. Pengolahan aneka saus. Jakarta: Ebook Pangan; 2009.

7. Setiono G. Kajian sifat fungsional tepung dari beberapa varietas beras. Skripsi. Fakultas Teknik Pertanian. Universitas Katolik Widiya Mandala: Surabaya; 2007.

8. Suprapti L. Membuat saus tomat. Trubus Agrisana: Surabaya; 2000. 
9. Susanti A. Penggunaan kappa karagenan sebagai bahan penstabil saos tomat. Fakultas Pertanian dan Kelautan. Institut Pertanian: Bogor; 2005.

10. Radiyanti $T$ dan AgustoWM. Tepung tapioka. BPTTG. Puslitbang; 1990.

11. Winarno FG. Teknologi pengolahan jagung. Badan Penelitian dan Pengembangan Pertanian. Pusat Penelitian dan Pengembangan Tanaman Pangan; 1988.

12. Susanti K, Taruna I, Sutarsi. Kajian sifat fisik tepung kecambah kacang hijau hasil pengeringan fluidized bed dryer. Jurnal Ilmiah Indonesia.Vol 4:(2) 91-105; 2015.

13. Haryoto. Membuat saus tomat. Jakarta: Kanisius; 1998.

14. Badan Standarisasi Nasional. SNI 013546-2004.Saus tomat: Jakarta; 2004.

15. Rangga, S.Manual of analysis of fruit and vegetable products.New Delhi: Tata Mc.Graw Hill; 1977.

16. Sutuhu S. Penanganan dan pengolahan buah. Jakarta:Penebar Swadaya; 1996.
17. Buckle KA, Edward RA, Fleet $\mathrm{GH}$, Wooton. 1987. Ilmu pangan. Terjemahan: H. Purnomo dan Adiono. Jakarta: Universitas Indonesia Press; 1987.

18. Winarno. Enzim angan. Jakarta: Gramedia Pustaka Utama; 1995.

19. Badan Standarisasi Industri. SNI 01.02222-1995. Bahan tambahan makanan: Jakarta; 1995.

20. Alam MD.Ahmed KM, Akter S, Islam N. Effect of carboxy methyl celullose and starch ast thickening agents on the quality of tomato ketchup.Pakistan Journal of Nutrition; 2009. 8(8):11441149.

21. Winarno FG. Teknologipengolahan rumput Laut. Jakarta: Pusat Sinar Harapan; 1990.

22. Campo VL, Kawano DF, da Silva DB, Carvalho I. Carrageenans: Biological properties, chemical modifications and structural analysis-A review. Carbohydrate Polymers. 2009 Jun 10;77(2):167-80.

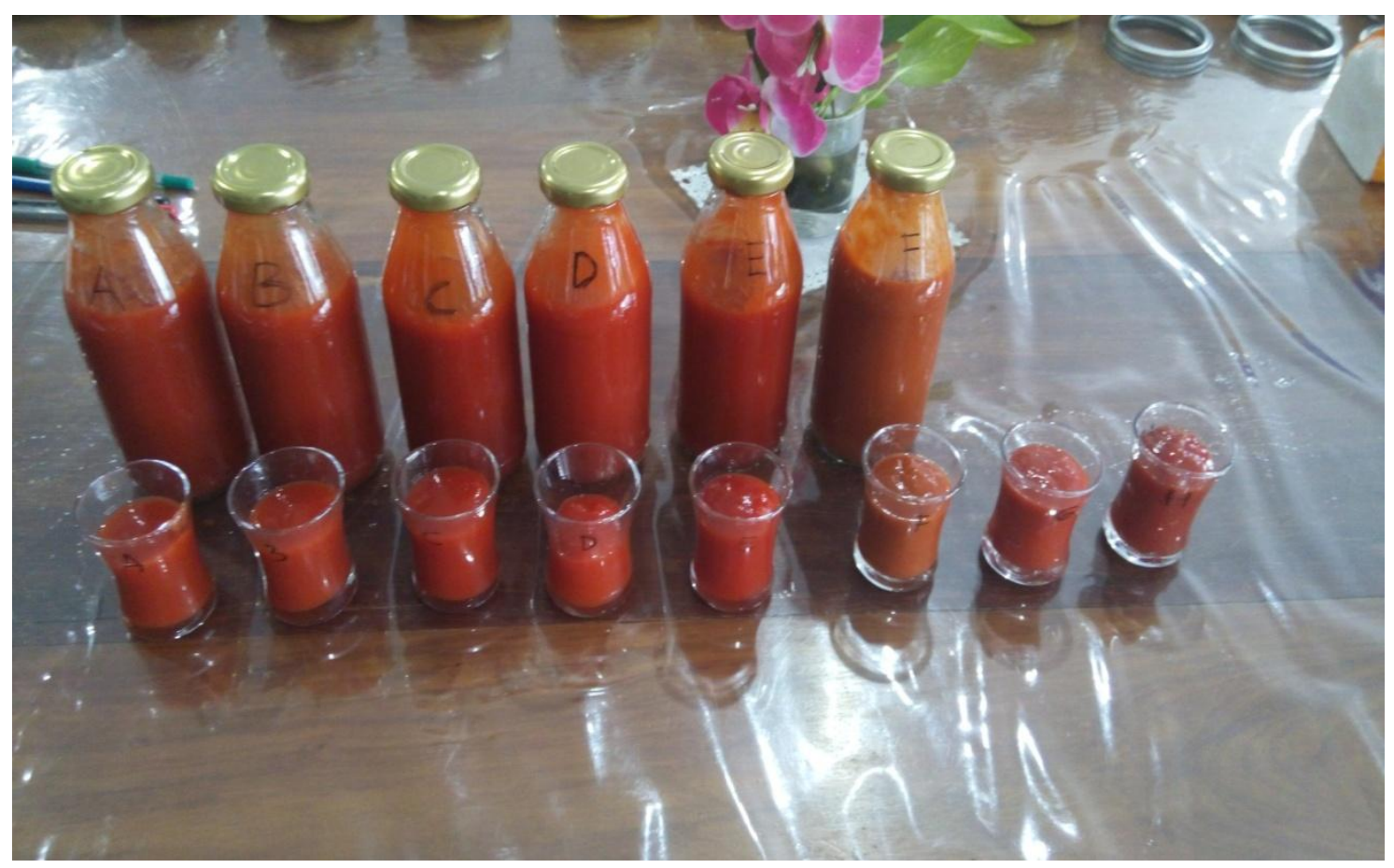

Produk Saus Tomat 